\title{
BRI2 (ITM2b) Inhibits A $\beta$ Deposition In Vivo
}

\author{
Jungsu Kim, ${ }^{1}$ Victor M. Miller, ${ }^{1}$ Yona Levites, ${ }^{1}$ Karen Jansen West, ${ }^{1}$ Craig W. Zwizinski, ${ }^{1}$ Brenda D. Moore, ${ }^{1}$ \\ Fredrick J. Troendle, ${ }^{1}$ Maralyssa Bann, ${ }^{1}$ Christophe Verbeeck, ${ }^{1}$ Robert W. Price, ${ }^{1}$ Lisa Smithson, ${ }^{1}$ Leilani Sonoda, ${ }^{1}$ \\ Kayleigh Wagg, ${ }^{1}$ Vijayaraghavan Rangachari, ${ }^{1}$ Fanggeng Zou, ${ }^{1}$ Steven G. Younkin, ${ }^{1}$ Neill Graff-Radford, ${ }^{2}$ \\ Dennis Dickson, ${ }^{1}$ Terrone Rosenberry, ${ }^{1}$ and Todd E. Golde ${ }^{1}$ \\ Departments of ${ }^{1}$ Neuroscience and ${ }^{2}$ Neurology, Mayo Clinic College of Medicine, Mayo Clinic Jacksonville, Jacksonville, Florida 32224
}

\begin{abstract}
Analyses of the biologic effects of mutations in the BRI2 (ITM $2 b$ ) and the amyloid $\beta$ precursor protein (APP) genes support the hypothesis that cerebral accumulation of amyloidogenic peptides in familial British and familial Danish dementias and Alzheimer's disease (AD) is associated with neurodegeneration. We have used somatic brain transgenic technology to express the BRI2 and BRI2-A $\beta 1-40$ transgenes in APP mouse models. Expression of BRI2-A $\beta 1-40$ mimics the suppressive effect previously observed using conventional transgenic methods, further validating the somatic brain transgenic methodology. Unexpectedly, we also find that expression of wild-type human $\mathrm{BRI} 2$ reduces cerebral $\mathrm{A} \beta$ deposition in an $\mathrm{AD}$ mouse model. Additional data indicate that the 23 aa peptide, Bri23, released from BRI2 by normal processing, is present in human CSF, inhibits $\mathrm{A} \beta$ aggregation in vitro and mediates its anti-amyloidogenic effect in vivo. These studies demonstrate that BRI2 is a novel mediator of $A \beta$ deposition in vivo.
\end{abstract}

Key words: BRI2; ITM2b; amyloid $\beta$ protein; Alzheimer's disease; somatic brain transgenesis; adeno-associated virus

\section{Introduction}

Familial British and Danish dementias (FBD and FDD, respectively) are neurodegenerative dementias pathologically characterized by parenchymal preamyloid and amyloid deposits, cerebral amyloid angiopathy (CAA), neuronal loss, and neurofibrillary tangles (Ghiso et al., 2006). Two mutations in the $I T M 2 b$ gene encoding the BRI2 protein have been identified as the cause of FBD and FDD. BRI2 is a 266-aa-long type 2 transmembrane protein of unknown function. It is expressed at high levels in the brain and cleaved by furin or furin-like proteases at its $\mathrm{C}$ terminus to produce a 23 aa peptide (Bri2-23) (Kim et al., 1999; Choi et al., 2004) (Fig. 1B). Disease-causing mutations result in the production of C-terminally extended 277 aa mutant BRI2 proteins, which are cleaved at the normal furin processing site to generate distinct 34 aa peptides (ABri in FBD and ADan in FDD) that accumulate in the brains of affected patients (Vidal et al., 1999, 2000). Notably, synthetic ABri and ADan undergo rapid aggregation and fibrillization into amyloid, and they are neurotoxic (Gibson et al., 2005; Ghiso et al., 2006). Thus, there are clear

Received Feb. 28, 2008; revised May 2, 2008; accepted May 4, 2008.

This work was supported by the National Institutes of Health-National Institute on Aging (NIA) Grant R01 AG18454 (T.E.G.) and the Robert H. and Clarice Smith and Abigail Van Buren Alzheimer's Disease Research Program (T.E.G.); Robert and Clarice Smith Postdoctoral Fellowship (B.D.M., V.M.M.); Development Award 0535185N from the American Heart Association (V.R.); and The Mayo Foundation. We thank Dr. Eileen McGowan for providing the BRI2 CDNA. We acknowledge the technical assistance of Linda Rousseau, Virginia Phillips, Monica Casey-Castanedes, and John Gonzales in the Neuropathology Laboratory at Mayo Clinic Jacksonville, which is supported by the NIA Grants AG25711, AG17216, and AG03949 (D.D.).

This article is freely available online through the J Neurosci Open Choice option.

Correspondence should be addressed to either Terrone Rosenberry (regarding A $\beta /$ Bri2-23 aggregation studies) or Todd E. Golde (all other correspondence), Department of Neuroscience, Mayo Clinic College of Medicine, Mayo Clinic Jacksonville, 4500 San Pablo Road, Jacksonville, FL 32224, E-mail: rosenberry@mayo.edu or tgolde@mayo.edu.

DOI:10.1523/JNEUROSCI.0891-08.2008

Copyright $\odot 2008$ Society for Neuroscience $\quad$ 0270-6474/08/286030-07\$15.00/0 pathological and clinical similarities between FBD, FDD, and Alzheimer's disease (AD). Indeed, genetic analyses of FBD, FDD, and familial forms of AD support a unifying pathologic mechanism in which accumulation of amyloidogenic peptides triggers a complex pathological cascade leading to neurodegeneration (Golde, 2003).

Our interest in the BRI2 protein developed in the course of studies using BRI2-A $\beta$ fusion proteins to express individual $\mathrm{A} \beta$ peptides (McGowan et al., 2005; Kim et al., 2007). By crossing BRI2-A $\beta 1-40$ or BRI-A $\beta 1-42$ transgenic mice with Tg2576 mice, we previously demonstrated that $\mathrm{A} \beta 1-40$ and $\mathrm{A} \beta 42$ have opposing effects on amyloid deposition (McGowan et al., 2005; Kim et al., 2007). To study the anti-amyloidogenic effect of $\mathrm{A} \beta 1-40$ in another amyloid $\beta$ precursor protein (APP) mouse model, we used recombinant adeno-associated virus 1 (rAAV1)mediated gene transfer to deliver the BRI2-A $\beta 1-40$ and BRI2 transgenes to the brains of postnatal day 0 (P0) TgCRND8 hAP$\mathrm{P}_{\mathrm{KM} 670 / 671 \mathrm{NL}+\text { V717F }}$ APP mice (Levites et al., 2006b). This methodology of gene transfer, which we have termed somatic brain transgenesis, leads to consistent widespread and permanent expression of the transgene in forebrain and hippocampal neurons (Fig. $1 \mathrm{~A}$ ) and enables one to rapidly and cost-effectively evaluate the effects of transgene expression on the amyloid deposition phenotype (Levites et al., 2006b).

\section{Materials and Methods}

rAAV1 construction and preparation. rAAV1 expressing BRI2, BRI2A $\beta 1-40$, BRI2del244-266, nonspecific single-chain variable fragment (scFv ns), or enhanced green fluorescent protein (eGFP), under the control of the cytomegalovirus enhancer/chicken $\beta$ actin (CBA) promoter were generated by calcium-phosphate transfection of pAM/CBA-pIWPRE-BGH, rAAV1 cis-plasmid pH21 (AAV1 helper plasmid), and pF $\Delta 6$ into a HEK293 cell line. rAAV1-scFv ns construct was reported previously (Levites et al., 2006b). At $48 \mathrm{~h}$ after transfection, cells were 
A

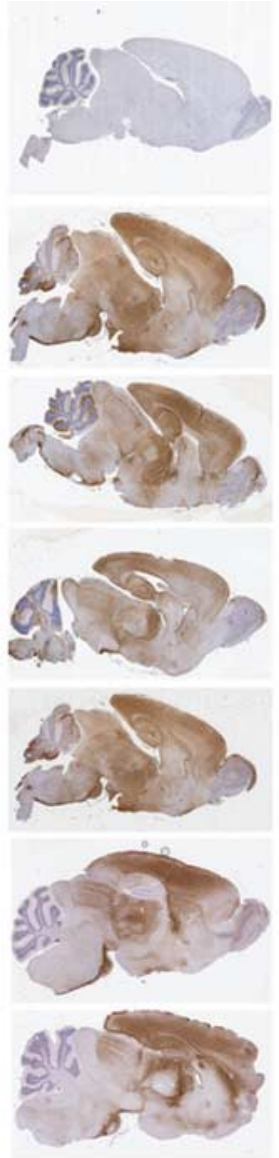

B

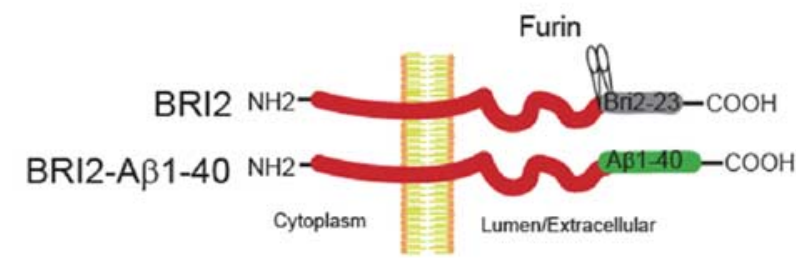

D

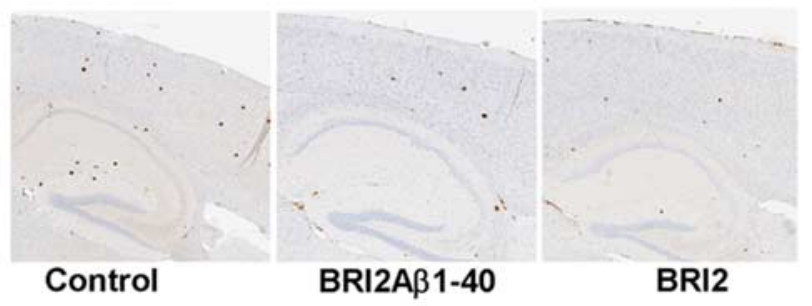

C

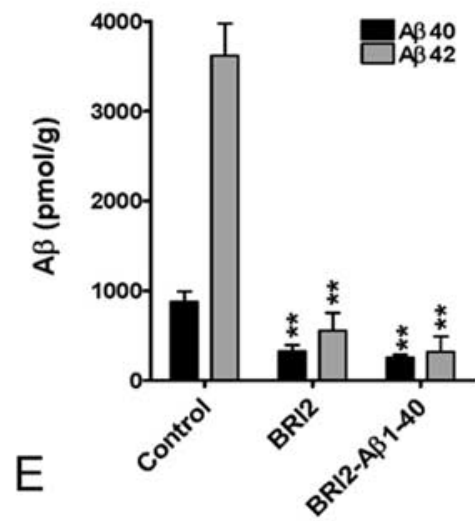

$A \beta$ plaque burden (\% area) $\square$ Thio S plaques/section

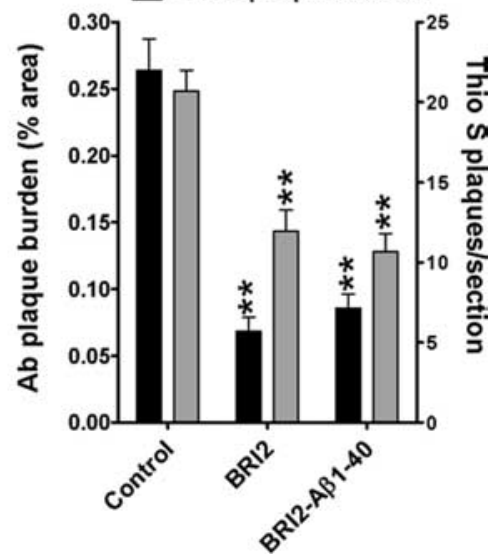

Figure 1. BRI2 expression inhibits $A \beta$ deposition in vivo. $A$, Somatic brain transgenesis results in consistent transduction of forebrain and hippocampal neurons. rAAV1-EGFP was delivered into cerebral ventricles of newborn mice $\left(4 \times 10^{9}\right.$ genomes per mouse), and widespread EGFP expression was detected by immunohistochemistry with an anti-GFP antibody at $\sim 1$ month of age. The top panel is a saline-injected control, and the next six panels are representative of three separate somatic brain transgenic experiments performed on four different litters using two different rAAV1-EGFP preparations. Note that the forebrain and hippocampus are routinely transduced, whereas hindbrain structures (e.g., cerebellum) are more variably transduced. $\boldsymbol{B}$, Schematic of BRI2-fusion constructs. BRI2 and BRI2-A $\beta 1-40$ are cleaved by furin and other kex2 proteases to release Bri2-23 and A $31-40$, respectively. C, P0 TgCRND8 mice were transduced by the intracerebroventricular injection of rAAV1-BRI2 $(n=8)$ or BRI2-A $\beta 1-40(n=11)$. Total brain A $\beta$ levels (pooled values of the SDS-soluble and SDS-insoluble FA extracts) from 3-month-old mice were analyzed by $A \beta$ end-specific ELISA. Control refers to both noninjected and PBS-injected mice $(n=8)$. $\boldsymbol{D}$, Cortical sections of 3-month-old mice were immunostained with anti-A $\beta 1-16$ antibody 33.1.1. Sections representing the mice with the median levels of biochemical $A \beta$ deposition are shown. CAA was not increased by the BRI transgenes and was almost completely absent in the TgCRND8 mice at 3 months of age. Magnification, 200X.E, Amyloid plaque burdens and thioflavin (Thio S)-positive plaques were quantified from the stitched images of whole cerebral cortex. Cored plaques, identified by Thio $S$ staining, were counted individually. ${ }^{* *} p<0.01$ versus no injection control (ANOVA).

lysed in the presence of $0.5 \%$ sodium deoxycholate and $50 \mathrm{U} / \mathrm{ml}$ benzonase (Sigma) by repeated rounds of freeze/thaws at $-80^{\circ} \mathrm{C}$ and $-20^{\circ} \mathrm{C}$. The virus was isolated using a discontinuous Iodixanol gradient and then affinity purified on a HiTrap HQ column (GE Healthcare). Samples were eluted from the column and buffer exchanged to PBS using an Amicon Ultra 100 Centrifugation device (Millipore). The genomic titer of each virus was determined by quantitative PCR using the ABI 7900 (Applied Biosystems). The viral DNA samples were prepared by treating the virus with DNase I (Invitrogen), heat inactivating the enzyme, and then digesting the protein coat with Proteinase K (Invitrogen), followed by a second heat inactivation. Samples were compared against a standard curve of supercoiled plasmid.

rAAV1 injection to neonatal mice. TgCRND8 mice expressing mutant human APP (KM670/671NL and V717F) gene under the control of hamster prion promoter were reported previously (Chishti et al., 2001). Hemizygous male TgCRND8 mice were crossed with female B6C3F1 wild-type mice. Tg2576 mice expressing mutant human APP (KM670/ $671 \mathrm{NL}$ ) gene under the control of hamster prion promoter were reported previously (Hsiao et al., 1996). Hemizygous female Tg2576 mice were mated with male B6SJL wild-type mice. The injection procedures were performed as described previously (Passini et al., 2003; Broekman et al.,
2006; Levites et al., 2006b). Briefly, P0 pups were cryoanesthetized on ice for 5 min. Two microliters of AAV1 construct $\left(1 \times 10^{12}\right.$ genome particles $/ \mathrm{ml}$ ) were bilaterally injected into the cerebral ventricle of newborn mice using a $10 \mathrm{ml}$ Hamilton syringe with a 30 gauge needle. The pups were placed on a heating pad until they recovered from cryoanesthesia and then returned to their mother for further recovery. Negative control groups (total $n=20)$ were noninjection $(n=4)$, PBS injection $(n=4)$, eGFP $(n=5)$, and nonspecific scFv $(n=7)$ groups. Experimental groups were BRI2-A $\beta 1-40(n=11)$, BRI2 $(n=8)$, and BRI2del244-266 $(n=$ 13 ). Biochemical and histochemical $A \beta$ loads in the control groups were equivalent. All animal procedures were approved by Mayo Clinic Institutional Animal Care and Use Committee in accordance with National Institutes of Health (NIH) guidelines.

Quantification of amyloid deposition. Hemibrains were immersion fixed in $10 \%$ formalin then processed for paraffin embedding. Brain tissue sections $(5 \mu \mathrm{m})$ were immunostained with the anti-total $\mathrm{A} \beta$ antibody [33.1.1; 1:1000 (Levites et al., 2006a)] on a DAKO autostainer. The cortical $\mathrm{A} \beta$ plaque burden and the number of Thio S-positive plaques were quantified as previously reported (Kim et al., 2007). Three to six sagittal sections per brain, $50 \mu \mathrm{m}$ apart, were analyzed.

$A \beta$ sandwich ELISA. For brain A $\beta$ ELISAs from TgCRND8 mice, 
hemi-forebrains were homogenized in $2 \%$ SDS with $1 \times$ protease inhibitor mixture (Roche) dissolved in $\mathrm{H}_{2} \mathrm{O}$ and then ultracentrifuged at $100,000 \times g$ for $1 \mathrm{~h}$. The SDS-insoluble $\mathrm{A} \beta$ peptides were extracted using $70 \%$ formic acid (FA). For brain A $\beta$ ELISAs from 2-month-old Tg2576 mice, hemi-forebrains were homogenized in radioimmunoprecipitation assay buffer $(0.1 \%$ SDS, $0.5 \%$ deoxycholate, $1 \%$ Triton X-100, $150 \mathrm{~mm}$ $\mathrm{NaCl}$, and $50 \mathrm{~mm}$ Tris- $\mathrm{HCl}$ ) and then ultracentrifuged at $100,000 \times \mathrm{g}$ for $1 \mathrm{~h}$. To measure the endogenous mouse $A \beta$ levels, hemi-forebrains of nontransgenic littermates of the TgCRND8 mice expressing BRI2 were homogenized in $0.2 \%$ diethylamine buffer containing $50 \mathrm{~mm} \mathrm{NaCl}$ and $1 \times$ protease inhibitor mixture (Roche). Endogenous mouse $\mathrm{A} \beta$ levels were measured using the previously validated rodent-specific A $\beta$ ELISA system as previously reported (Eckman et al., 2006). For plasma A $\beta$ analysis, blood was collected in EDTA-coated tubes after cardiac puncture. Blood samples were centrifuged at $3000 \mathrm{rpm}$ for $10 \mathrm{~min}$ at $4^{\circ} \mathrm{C}$, and then the plasma was aliquoted and stored at $-80^{\circ} \mathrm{C}$ until used. $\mathrm{A} \beta$ levels were determined by human $\mathrm{A} \beta$ end-specific sandwich ELISAs as previously described (Kim et al., 2007).

Mouse anti-A $\beta$ IgG ELISA. To test whether mice generate anti-A $\beta$ antibody responses, anti-A $\beta$ IgG antibody titers were determined by standard ELISA techniques, as described previously (Das et al., 2001). Briefly, microtiter plates (Maxi Sorp; Dynatech) were coated with aggregated $\mathrm{A} \beta 42$ at $2 \mu \mathrm{g} /$ well. After washings, serial dilutions of plasma (1:500 dilution) were added and incubated overnight at $4^{\circ} \mathrm{C}$. After washes with PBS/0.1\% Tween 20, plasma IgG was detected using an anti-mouse IgG antibody conjugated with HRP (1:2000; Sigma) and TMB substrate (KPL).

Western blotting. Snap-frozen forebrain samples were homogenized in $2 \%$ SDS buffer with $1 \times$ protease inhibitor mixture (Roche). The homogenate was centrifuged at $100,000 \times g$ for $1 \mathrm{~h}$ at $4^{\circ} \mathrm{C}$. Protein concentration in supernatants was determined using the BCA Protein Assay kit (Pierce). Protein samples $(20 \mu \mathrm{g})$ were run on Bis-Tris $12 \%$ XT gels (Bio-Rad) with XT-MES buffer or Bis-Tris $4-12 \%$ XT gels (Bio-Rad) with XT-MOPS buffer and transferred to $0.2 \mu \mathrm{m}$ nitrocellulose membranes. Blots were microwaved for $2 \mathrm{~min}$ in $0.1 \mathrm{M}$ PBS twice and probed with the antibody $82 \mathrm{E} 1$ (anti-A $\beta 1-16 ; 1: 1000 ;$ IBL), CT20 (anti-APP C-terminal 20 aa; 1:1000; T. E. Golde) and ITM2b (GenWay). Blots were stripped and reprobed with anti $\beta$-actin (1:1000; Sigma) as a loading control. Relative band intensity was quantified using Image software (NIH).

In vitro $A \beta$ aggregation assay using native gel electrophoresis. Synthetic $\mathrm{A} \beta 1-42$ and $\mathrm{A} \beta 1-40$, treated with hexafluoroisopropanol and dried (Bachem), and Bri2-23 peptides (Bachem) were dissolved in DMSO and then diluted in TBS at molar ratios as indicated. A $\beta 1-42$ and Bri2-23 peptide mixtures were incubated for $3 \mathrm{~h}$ at either $0^{\circ} \mathrm{C}$ or $37^{\circ} \mathrm{C}$ without shaking. Mixtures were run on 4-20\% Tris- $\mathrm{HCl}$ gels under nondenaturing conditions and transferred to $0.4 \mu \mathrm{m}$ polyvinylidene fluoride membrane as previously described (Klug et al., 2003; Kim et al., 2007). The blot was probed with Ab9 (anti-A $\beta 1-16 ; 1: 1000 ;$ T. E. Golde). Relative band intensity was quantified using ImageJ software (NIH).

In vitro $A \beta 1-42$ aggregation assay using thioflavin $T$ and atomic force microscopy studies. Bri2-23 peptides (Bachem) were reconstituted in 1 $\mathrm{mg} / \mathrm{ml}$ Tris- $\mathrm{HCl}, \mathrm{pH}$ 8.0. The lyophilized synthetic A $\beta 1-42$ (Mayo Clinic Peptide Synthesis Facility) was dissolved at 0.5-2.0 mm in $20 \mathrm{~mm}$ $\mathrm{NaOH} 15$ min before size exclusion chromatography on Superdex $75 \mathrm{HR}$ $10 / 30$ column (GE Healthcare) to remove any preformed $A \beta$ aggregates. The concentration of monomeric $\mathrm{A} \beta$ was determined by $\mathrm{UV}$ absorbance with a calculated extinction coefficient of $1450 \mathrm{~cm}^{-1} \times \mathrm{M}^{-1}$ at $276 \mathrm{~nm}$ (Rangachari et al., 2006). A $\beta 1-42$ aggregation reactions were initiated in siliconized Eppendorf tubes by incubating 25-50 $\mu \mathrm{M}$ freshly purified $\mathrm{A} \beta 1-42$ monomer in $10 \mathrm{~mm}$ Tris- $\mathrm{HCl}$ and $150 \mathrm{~mm} \mathrm{NaCl}, \mathrm{pH}$ 8.0, buffer without agitation at $37^{\circ} \mathrm{C}$. Monomeric $\mathrm{A} \beta 1-42$ aggregation process in the presence or absence of Bri2-23 peptide were monitored using a thioflavin T (ThT) assay as previously reported (Rangachari et al., 2006). Atomic force microscopy images were obtained with a NanoScope III controller with a Multimode AFM (Veeco Instruments) as described previously (Nichols et al., 2005). Images are shown in amplitude mode, where increasing brightness indicates greater damping of cantilever oscillation.
HPLC/mass spectrometry analysis of Bri2-23 peptides. Conditioned media or CSF was filtered through a $0.45 \mu \mathrm{M}$ syringe filter to remove large particulate matter. A $50 \mu \mathrm{l}$ aliquot of the sample was injected into an Agilent 1100 Series HPLC with a Zobax Eclipse XDB-C8 column and running buffer of acetonitrile $/ \mathrm{H}_{2} \mathrm{O}\left(\mathrm{ACN}: \mathrm{H}_{2} \mathrm{O}\right)$ with $0.1 \%$ trifluoroacetic acid (TFA) at a flow rate of $1 \mathrm{ml} / \mathrm{min}$. Initial solvent composition was 20:80 ACN/ $\mathrm{H}_{2} \mathrm{O}$; this composition was held for $3 \mathrm{~min}$ and then linearly ramped up to $37: 63 \mathrm{ACN} / \mathrm{H}_{2} \mathrm{O}$ over the next $7 \mathrm{~min}$. A fraction was collected between 9.4 and $10.4 \mathrm{~min}$ (as the BRI-23 standard was seen to elute at $9.8 \mathrm{~min}$ ) for a total of $1 \mathrm{ml}$.

The collected fraction was then blown down in nitrogen at $37^{\circ} \mathrm{C}$ to $\sim 100 \mu \mathrm{l}$ in volume. A $1 \mu \mathrm{l}$ aliquot of this concentrated sample was applied to a Bio-Rad gold array chip and allowed to air dry. After the sampled dried, $1 \mu \mathrm{l}$ of saturated $\alpha$-cyano-4-hydroxycinnamic acid (MALDI matrix) in 70:20:10 ACN: $\mathrm{H}_{2} \mathrm{O}: \mathrm{MeOH}$ with $0.1 \%$ TFA was applied on top of dried sample and allowed to air dry. This was then analyzed on a Bio-Rad Ciphergen ProteinChip SELDI time-of-flight system. A laser intensity of $750 \mu \mathrm{J}$ was used to collect spectra from 3975 laser shots, which were averaged into the final spectra. The finished spectra were baseline corrected.

Statistical analysis. One-way ANOVA with post hoc Holm-Sidak multiple-comparison test or two-tailed Student's $t$ test was used for statistical comparison (SigmaStat 3.0 version). If the data did not meet the parametric test assumptions, nonparametric statistics was performed, either Kruskal-Wallis test (one-way ANOVA on ranks) followed by post hoc Dunn's multiple-comparison procedures or Mann-Whitney rank sum test (SigmaStat 3.0 version). Variability of the estimates was reported as SEM.

\section{Results}

\section{BRI2 and BRI2-A $\beta 1-40$ suppress amyloid deposition in APP transgenic mice}

The effects of the virally delivered BRI2-A $\beta 1-40$ transgene were compared with effects of the rAAV1-delivered human BRI2 transgene and a noninjection control (Fig. 1B). Expression of BRI2 was intended to serve as a second control, because we had established that rAAV1-hGFP delivery and mock virus delivery did not alter $\mathrm{A} \beta$ deposition in the CRND8 APP mouse model (Levites et al., 2006b). Three months after rAAV1-mediated transgene delivery, mice were killed and brain $\mathrm{A} \beta$ deposition was analyzed using both biochemical and histochemical methods. These analyses revealed a dramatic suppressive effect of both the BRI2-A $\beta 1-40$ and BRI2 transgenes on parenchymal $A \beta 1-40$ and $A \beta 1-42$ accumulation as measured by biochemical and histochemical assessments of $\mathrm{A} \beta$ levels (Fig. $1 C-E$ ).

The reduction in $\mathrm{A} \beta$ deposition observed in the mice expressing the rAAV1 BRI2-A $\beta 1-40$ transgene was consistent with our previous transgenic mice studies (Kim et al., 2007), whereas the reduction of $\mathrm{A} \beta$ deposition observed in the mice expressing BRI2 was unexpected. Previous studies had demonstrated a potential interaction between BRI2 and APP and noted that BRI2 overexpression increased APP C-terminal fragment $\beta(\mathrm{CTF} \beta)$ and reduced $\mathrm{A} \beta$ secretion in cultured cells (Fotinopoulou et al., 2005; Matsuda et al., 2005). As in the studies of BRI2-A $\beta$ transgenic mice crossed into Tg2576 mice (McGowan et al., 2005; Kim et al., 2007), we found no evidence for alterations in the steady-state levels of APP or APP CTF $\beta$ in TgCRND8 mice expressing the virally delivered BRI2-A $\beta 1-40$ or BRI2 transgenes (Fig. $2 A, B$ ). Moreover, levels of endogenous rodent $A \beta$ levels in the brains of the nontransgenic littermates of the TgCRND8 mice expressing the BRI2 transgene were not altered (Fig. $2 C$ ). BRI2-A $\beta 1-40$ expression slightly increased plasma $\mathrm{A} \beta 40$ levels, attributable to brain to plasma efflux of $A \beta 1-40$; plasma $A \beta 1-42$ levels were not significantly changed by BRI2 expression (Fig. $2 D$ ). Because of the rapid onset of $A \beta$ deposition in TgCRND8 mice, it is not 
possible to measure steady-state $\mathrm{A} \beta$ levels; therefore, we conducted additional experiments in $\operatorname{Tg} 2576$ mice to determine whether BRI2 altered steady-state A $\beta$ before plaque deposition. rAAV1-mediated delivery of BRI2 to P0 Tg2576 did not lower steady-state $A \beta$ levels in brains of 2 -month-old mice. (Fig. 2E). Because anti-A $\beta$ antibodies reduce $A \beta$ deposition in mice and expression of virally encoded $\mathrm{A} \beta$ peptides in the periphery has been shown to generate an anti-A $\beta$ response, we examined whether CNS delivery of the transgene induced a humoral immune response to $A \beta$. There was no evidence for an anti-A $\beta$ titer in any of the rAAV1injected mice (Fig. $2 F$ ). Collectively, these results in TgCRND8, wild-type TgCRND8 littermates, and $\operatorname{Tg} 2576$ mice demonstrate that the reduction of $\mathrm{A} \beta$ accumulation by BRI2 and BRI2-A $\beta 1-40$ transgenes was not likely to be attributable to alterations in APP processing resulting from altered $\mathrm{A} \beta$ production or induction of an anti-A $\beta$ immune response.

\section{Bri2-23 inhibits $A \beta 1-42$ aggregation in vitro}

To understand the mechanism by which BRI 2 reduced $A \beta$ accumulation, we tested whether the Bri2-23 peptide could directly inhibit $\mathrm{A} \beta 1-42$ fibrillogenesis in vitro. Several methods were used, including a native gel assay previously used to demonstrate that $\mathrm{A} \beta 1-40$ inhibits $\mathrm{A} \beta 1-42$ aggregation (Kim et al., 2007). When $\mathrm{A} \beta 1-42$ aggregation was assessed using the native gel assay, we observed loss of the monomeric A $\beta 1-42$ signal and the appearance of high-molecular weight (HMW) aggregates (Fig. 3A, lane 10). Addition of Bri2-23 or $A \beta 1-40$ to the reaction resulted in retention of the monomeric $A \beta 1-42$ signal, suggesting direct inhibition of aggregation (Fig. $3 A$, compare lane 10 with lanes 4,6 , and 8). Quantification by an ELISA capable of only recognizing monomeric $\mathrm{A} \beta$ confirmed that the Bri2-23 peptide retained $A \beta 1-42$ in its monomeric state, and this effect was more robust with increasing concentrations of Bri2-23 (Fig. 3B). To further analyze the effect of Bri2-23 on A $\beta$ aggregates, we examined the effect of equimolar concentrations $(25$ or $50 \mu \mathrm{M})$ of the Bri2-23 peptide on monomeric $A \beta 1-42$ aggregation into $A \beta 1-42$ fibrils or protofibrils using ThT fluorescence assay. Prolonged incubations of Bri2-23, by itself, did not result in aggregation or $\beta$-sheet formation as assessed by ThT fluorescence assay, change in circular dichroism spectra, or insolubility (data not shown) (Gibson et al., 2005). Coaggregation of $A \beta 42$ and Bri2-23 demonstrates that Bri2-23 appears to initially increase the rate of aggregate formation during the first $12 \mathrm{~h}$ of incubation, but inhibits fibril formation at later time points (Fig. 3C). After 120-200 h of incubation, Bri2-23 inhibited A $\beta 1-42$ aggregation by $46 \pm 9 \%$ $(n=6 ; p=0.0004)$. Atomic force microscopy (AFM) imaging confirmed the inhibitory effects of Bri2-23 on A $\beta 1-42$ aggregation in these assays (Fig. 3D). These data show that Bri2-23 has a complex effect on aggregation of monomeric $\mathrm{A} \beta 1-42$; however,
B
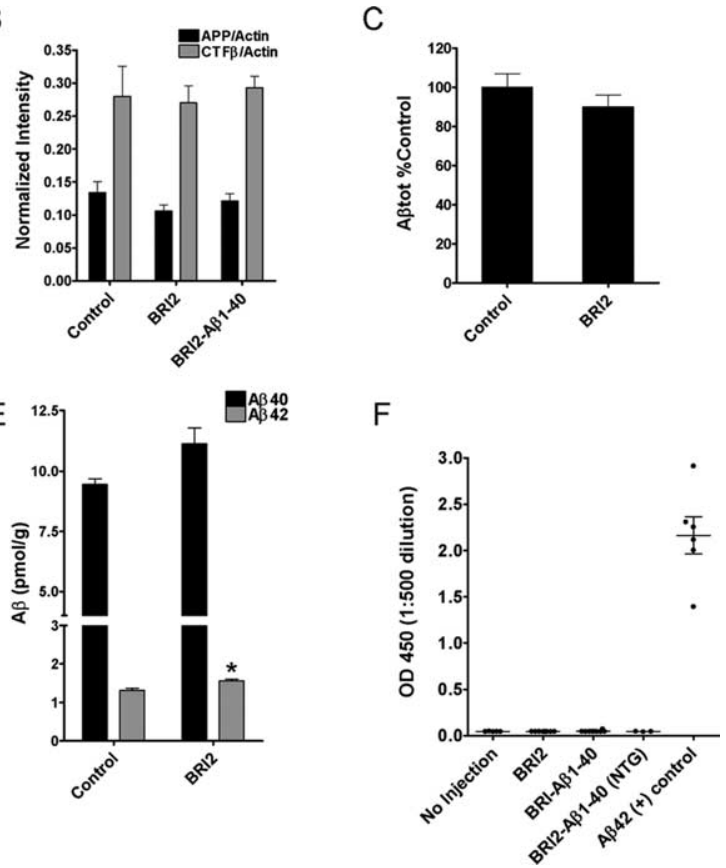

Figure 2. Effects of BRI2 and BRI2-A $\beta 1-40$ on steady-state levels of $A P P, A P P C T F$, and $A \beta$. $A$, To analyze whether APP panel, and the CRND8 hAPP transgene status is listed in parentheses. $\boldsymbol{B}$, Quantification of APP and CTF $\beta$ protein level after 列 $\beta$-actin level showed no change in the relative levels of both proteins in all groups. $C$, The steady-state endogBRI expression does not result in a humoral immune response to $A \beta$. The levels of anti-A $\beta \lg G$ antibody in plasma were measured by anti-A $\beta$ antibody ELISA. Cerebral expression of BRI2 and BRI2-A $\beta 1-40$ in TgCRND8 mice did not trigger anti-A $\beta$ immune response in all groups, except in the positive control group immunized with fibrillar $A \beta 42$.

both assays are consistent with a net inhibitory effect of Bri2-23 peptide on amyloid formation, presumably through inhibition of a later stage in fibril assembly.

\section{The Bri2-23 sequence is required to suppress $A \beta$ deposition} in vivo

These observations suggested that the anti-amyloidogenic effect of the BRI2 protein is mediated by an interaction between Bri2-23 and $A \beta$. To further test this idea in vivo, we generated a CDNA that expresses a truncated BRI2 protein lacking the Bri2-23 peptide (BRI2del244-266) (Fig. 4A) and used rAAV gene transfer to deliver this construct to newborn TgCRND8 mice. Transgene positive mice were killed at 3 months of age, and biochemical and histochemical $A \beta$ loads were examined. Analyses of $A \beta$ loads showed no significant difference between BRI2del244-266 and the control groups (Fig. $4 B-D$ ). Western blot analyses of brain lysates demonstrated that the somatic brain transgenic methodology produced approximately equivalent expression levels from the BRI2 and BRI2del244-266 constructs and somewhat higher levels from BRI2-A $\beta 1-40$ (Fig. $4 E$ ). These later data and the lack of anti-amyloidogenic effect from BRI2del244-266 demonstrate that the Bri2-23 peptide sequence is critical for the inhibitory effect of BRI2 in vivo. Together with the data demonstrating that Bri2-23 directly inhibits $A \beta$ aggre- 
A

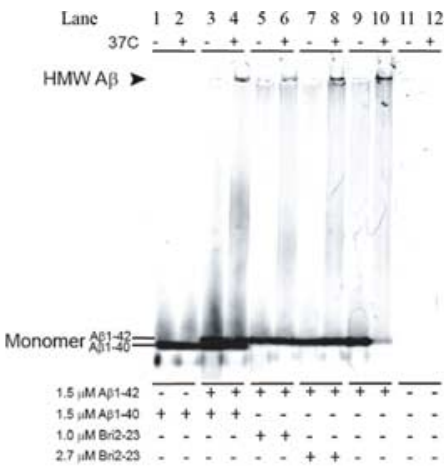

C

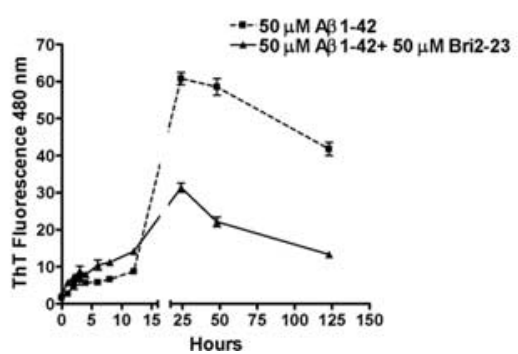

B

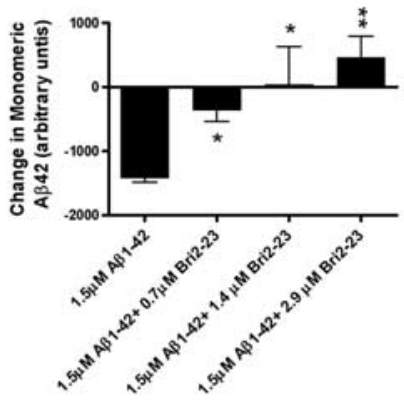

D

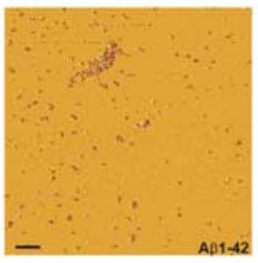

Figure 3. Bri2-23 peptide inhibits $A \beta$ aggregation in vitro. $A$, Synthetic $A \beta 1-42, A \beta 1-40$, and Bri2-23 peptides were mixed at the concentrations indicated and incubated at 0 or $37^{\circ} \mathrm{C}$ or $3 \mathrm{~h}$. After incubation, the extent of $A \beta$ aggregation into HMW aggregates was assessed by native gel electrophoresis and Western blotting with $A b 9$ (anti-A $\beta 1-16$ ) antibody that recognizes $A \beta$ fibrils, oligomers, and monomers. $B$, Quantitative analysis of a second dose-response study showed the difference in monomeric $A \beta 1-42$ levels between the 37 and $0^{\circ} \mathrm{C}$ incubations. $n=3$ for each condition. ${ }^{*} p<0.05$ and ${ }^{* *} p<0.01$ versus $1.5 \mu \mathrm{m}$ A $\beta 42$ aggregation (ANOVA). C, Monomeric A $\beta 1-42$ isolated by size-exclusion chromatography was incubated in the presence or absence of Bri2-23 peptide. At the indicated times, aliquots of aggregation reaction mixtures were analyzed for the extent of aggregation by ThT assay. D, AFM analysis of aggregates at $72 \mathrm{~h}$ of incubation. Representative images, shown in height mode, are $10 \times 10 \mu \mathrm{m}$. Scale bars, $1 \mu \mathrm{m}$.

gation in vitro, these data support an anti-amyloidogenic function for BRI2 mediated by the Bri2-23 peptide.

\section{The Bri2-23 peptide is present in human CSF}

Our mouse data suggested that endogenous BRI2 could function, at least in part, by secretion of the Bri2-23 peptide as an antiamyloidogenic binding partner of $\mathrm{A} \beta$. To date, studies of normal BRI2 processing and secretion relied mainly on epitope-tagged versions of the Bri2-23 peptide (Kim et al., 1999; Choi et al., 2004). First-generation antibodies were not sensitive enough to detect the Bri2-23 peptide in biological samples. Thus, we developed an HPLC/mass spectrometry (HPLC/MS)-based assay to detect secreted Bri2-23. We validated this methodology by detecting untagged Bri2-23 peptide secretion from $\mathrm{H} 4$ cells transfected with BRI2 but not BRIdel244-266 (Fig. 4F). We then tested normal human CSF and were able to detect the endogenously secreted Bri2-23 peptide in all samples tested (Fig. 4G). This finding strengthens the notion that the anti-aggregation effects of Bri2-23 peptide in our experiments may be physiologically relevant to human $\mathrm{AD}, \mathrm{FDD}$, and FBD.

\section{Discussion}

We have used somatic brain transgenic technology to deliver the BRI2 and BRI2-A $\beta 1-40$ transgenes to the brains of APP mouse models. The studies with BRI2-A $\beta 1-40$ confirmed previous studies obtained using conventional transgenic mice expressing BRI2-A $\beta 1-40$ (McGowan et al., 2005; Kim et al., 2007). Thus, the somatic brain transgenic BRI2-A $\beta 1-40$ studies provide additional validation for this rapid cost-effective method of manipulating gene expression in the brain (Levites et al., 2006b).

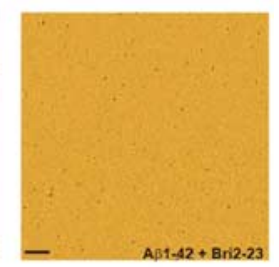

The novel result from these studies was the finding that BRI2 suppresses $\mathrm{A} \beta$ deposition in APP CRND8 transgenic mice to an extent equivalent to $A \beta 1-40$. Although it is not possible to completely rule out subtle effects on $\mathrm{A} \beta$ generation that could influence deposition, we found no evidence that the suppressive effect was mediated by alterations in APP processing or $\mathrm{A} \beta$ production. Instead, we find that the suppressive effect of BRI2 is likely to be mediated by inhibition of $A \beta$ aggregation by the secreted peptide. We demonstrate that expression of the BRI2del244-266 construct that lacks a secreted peptide sequence has no effect on $A \beta$ deposition after expression in vivo. BRI2del244-266 encodes a protein containing the region of BRI2 previously shown to interact with APP and interfere with APP processing in cell culture. Coupled with their inhibition of aggregation in vitro, we conclude that the $A \beta 1-40$ and Bri2-23 peptides are directly responsible for reduced $\mathrm{A} \beta$ deposition in our experiments rather than any other part of the BRI2 protein scaffold on which they were delivered. Notably, in FDD brains, $A \beta$ and the ADan peptide are codeposited and bind to each other in vitro (Tomidokoro et al., 2005). These later findings suggest that the FDD-linked BRI2 mutation may corrupt a normally protective anti-amyloidogenic mechanism resulting in coaggregation of the mutant peptide with a normal binding partner. In support of our observations, Bri2-23 contains the sequence FENKF that is homologous to peptide-based $\mathrm{A} \beta$ aggregation inhibitors incorporating a FxxxF motif (Sato et al., 2006). Moreover, solid-state nuclear magnetic resonance analysis demonstrated direct binding of an 8 aa peptide containing the sequence FEGKF with the glycine zipper (G33xxxG37) segment of $A \beta 1-40$, a sequence proposed to be critical for formation and stability of $\beta$-sheet structure (Liu et al., 2005; Sato et al., 2006).

Beyond the genetic link to FDD and FBD, little is known about the function of BRI2 and its homologues. BRI2 is encoded by the ITM2b gene located on chromosome 13q14.3, and is a member of a gene family consisting of BRI1 (ITM2A) and BRI3 (ITM2C) (Vidal et al., 2001; Akiyama et al., 2004; Choi et al., 2004). Orthologs are only found in higher eukaryotes. The BRI proteins share $\sim 50 \%$ identify at the amino acid level, and are all expressed at modest (BRI1) to extremely high levels in the brain (BRI2, BRI3). They are relatively small $(\sim 260$ aa) type 2 membrane proteins with single transmembrane domains, extracellular BRICHOS domains, and furin cleavage sites near their $\mathrm{C}$ termini. At their $C$ termini, they encode small peptides that, for BRI2 and BRI3, have been shown to be released and secreted after the furin cleavage (Kim et al., 1999; Wickham et al., 2005). Based on limited data, others have proposed that the BRICHOS domain targets the protein to the secretory pathway, performs an intramolecular chaperone-like function, and assists the specialized intracellular protease-processing system (Sanchez-Pulido et al., 2002). Very recently, BRI2 has been shown to undergo sequential cleavage by ADAM10 to release its ectodomain and intramem- 
brane proteolysis by SPPL2a and b (Martin et al., 2007). BRI2 has also been shown to undergo axonal transport (Choi et al., 2004). Nevertheless, other than the genetic link between BRI2 and FBD and FDD, almost nothing is known about the function of the BRI proteins (Ghiso et al., 2006).

Further study of BRI2 and the Bri2-23 peptide as well as analogous peptides released from the BRI2 homologues (which contain the conserved FxxxF motif) will be required to fully understand their antiamyloidogenic action and other functions. The robust inhibitory effect of BRI2 on $\mathrm{A} \beta$ deposition in vivo and aggregation in vitro BRI2 indicates that BRI2 is a novel factor that modulates $\mathrm{A} \beta$ aggregation and deposition. These data support a novel approach to AD therapy or prevention based on increasing levels of BRI2 and more specifically the Bri2-23 peptide in the brain.

\section{References}

Akiyama H, Kondo H, Arai T, Ikeda K, Kato M, Iseki E, Schwab C, McGeer PL (2004) Expression of BRI, the normal precursor of the amyloid protein of familial $\mathrm{Br}$ dementia, in human brain. Acta Neuropathol (Berl) 107:53-58.

Broekman ML, Comer LA, Hyman BT, SenaEsteves M (2006) Adeno-associated virus vectors serotyped with AAV8 capsid are more efficient than AAV-1 or - 2 serotypes for widespread gene delivery to the neonatal mouse brain. Neuroscience 138:501-510.

Chishti MA, Yang DS, Janus C, Phinney AL, Horne P, Pearson J, Strome R, Zuker N, Loukides J, French J, Turner S, Lozza G, Grilli M, Kunicki S, Morissette C, Paquette J, Gervais F, Bergeron C, Fraser PE, Carlson GA, et al. (2001) Early-onset amyloid deposition and cognitive deficits in transgenic mice expressing a double mutant form of amyloid precursor protein 695. J Biol Chem 276:21562-21570.

Choi SI, Vidal R, Frangione B, Levy E (2004) Axonal transport of Br and Danish amyloid peptides via secretory vesicles. FASEB J 18:373-375.

Das P, Murphy MP, Younkin LH, Younkin SG, Golde TE (2001) Reduced effectiveness of Abetal-42 immunization in APP transgenic mice with significant amyloid deposition. Neurobiol Aging 22:721-727.

Eckman EA, Adams SK, Troendle FJ, Stodola BA, Kahn MA, Fauq AH, Xiao HD, Bernstein KE, Eckman CB (2006) Regulation of steady-state betaamyloid levels in the brain by neprilysin and endothelin-converting enzyme but not angiotensin-converting enzyme. J Biol Chem 281:30471-30478.

Fotinopoulou A, Tsachaki M, Vlavaki M, Poulopoulos A, Rostagno A, Frangione B, Ghiso J, Efthimiopoulos S (2005) BRI2 interacts with amyloid precursor protein (APP) and regulates amyloid beta (Abeta) production. J Biol Chem 280:30768-30772.

Ghiso J, Rostagno A, Tomidokoro Y, Lashley T, Bojsen-Moller M, Braendgaard H, Plant G, Holton J, Lal R, Revesz T, Frangione B (2006) Genetic alterations of the BRI2 gene: familial $\mathrm{Br}$ and Danish dementias. Brain Pathol 16:71-79.

Gibson G, El-Agnaf OM, Anwar Z, Sidera C, Isbister A, Austen BM (2005) Structure and neurotoxicity of novel amyloids derived from the BRI gene. Biochem Soc Trans 33:1111-1112.

Golde TE (2003) Alzheimer disease therapy: can the amyloid cascade be halted? J Clin Invest 111:11-18.

Hsiao K, Chapman P, Nilsen S, Eckman C, Harigaya Y, Younkin S, Yang F,
D

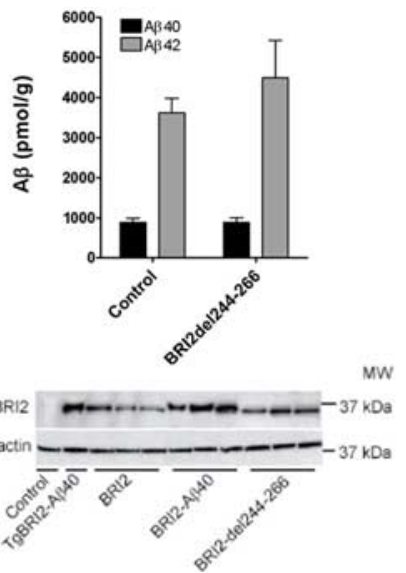

$\mathrm{F}$
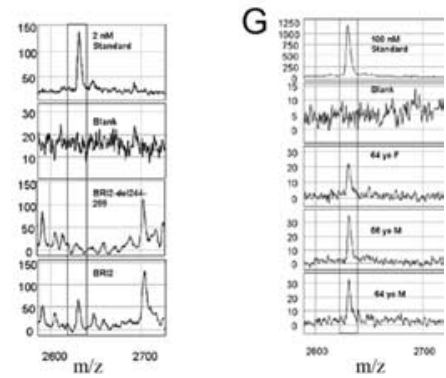

Figure 4. The Bri2-23 peptide is required for the anti-amyloidogenic effect of the BRI2 protein in vivo and is present in human CSF. A, Schematic of BRI2 and BRI2del244 -266 constructs. BRI2del244-266 construct does not encode the Bri2-23 peptide. PO CRND8 mice were transduced by intracerebroventricular injection of rAAV1-BRI2del244-266. B, C, Cortical sections (magnifi-

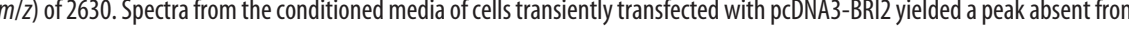
of three normal subjects each yielded a peak absent from the blank with an assessed mass-to-charge ratio nearly identical to the Bri2-23 peptide standard. yo, Years old; $F$, female; $M$, male.

Cole G (1996) Correlative memory deficits, Abeta elevation, and amyloid plaques in transgenic mice [see comments]. Science 274:99-102.

Kim J, Onstead L, Randle S, Price R, Smithson L, Zwizinski C, Dickson DW, Golde T, McGowan E (2007) A $\beta 40$ inhibits amyloid deposition in vivo. J Neurosci 27:627-633

Kim S-H, Wang R, Gordon D, Bass J, Steiner D, Lynn D, Thinakarn G, Meredith S, Sisodia S (1999) Furin mediates enhanced production of fibrillogenic ABri peptides in familial $\mathrm{Br}$ dementia. Nat Neurosci 2:984-988

Klug GM, Losic D, Subasinghe SS, Aguilar MI, Martin LL, Small DH (2003) Beta-amyloid protein oligomers induced by metal ions and acid $\mathrm{pH}$ are distinct from those generated by slow spontaneous ageing at neutral $\mathrm{pH}$. Eur J Biochem 270:4282-4293.

Levites Y, Das P, Price RW, Rochette MJ, Kostura LA, McGowan EM, Murphy MP, Golde TE (2006a) Anti-Abeta42- and anti-Abeta40-specific mAbs attenuate amyloid deposition in an Alzheimer disease mouse model. J Clin Invest 116:193-201.

Levites Y, Jansen K, Smithson LA, Dakin R, Holloway VM, Das P, Golde TE (2006b) Intracranial adeno-associated virus-mediated delivery of antipan amyloid $\beta$, amyloid $\beta 40$, and amyloid $\beta 42$ single-chain variable fragments attenuates plaque pathology in amyloid precursor protein mice. J Neurosci 26:11923-11928.

Liu W, Crocker E, Zhang W, Elliott JI, Luy B, Li H, Aimoto S, Smith SO (2005) Structural role of glycine in amyloid fibrils formed from transmembrane alpha-helices. Biochemistry 44:3591-3597.

Martin L, Fluhrer R, Reiss K, Kremmer E, Saftig P, Haass C (2007) Regu- 
lated intramembrane proteolysis of Bri2 (Itm2b) by ADAM10 and SPPL2a/b. J Biol Chem 283:1644-1652.

Matsuda S, Giliberto L, Matsuda Y, Davies P, McGowan E, Pickford F, Ghiso J, Frangione B, D'Adamio L (2005) The familial dementia BRI2 gene binds the Alzheimer gene amyloid-beta precursor protein and inhibits amyloid-beta production. J Biol Chem 280:28912-28916.

McGowan E, Pickford F, Kim J, Onstead L, Eriksen J, Yu C, Skipper L, Murphy MP, Beard J, Das P, Jansen K, Delucia M, Lin WL, Dolios G, Wang R, Eckman CB, Dickson DW, Hutton M, Hardy J, Golde T (2005) Abeta42 is essential for parenchymal and vascular amyloid deposition in mice. Neuron 47:191-199.

Nichols MR, Moss MA, Reed DK, Cratic-McDaniel S, Hoh JH, Rosenberry TL (2005) Amyloid-beta protofibrils differ from amyloid-beta aggregates induced in dilute hexafluoroisopropanol in stability and morphology. J Biol Chem 280:2471-2480.

Passini MA, Watson DJ, Vite CH, Landsburg DJ, Feigenbaum AL, Wolfe $\mathrm{JH}$ (2003) Intraventricular brain injection of adeno-associated virus type 1 (AAV1) in neonatal mice results in complementary patterns of neuronal transduction to AAV2 and total long-term correction of storage lesions in the brains of beta-glucuronidase-deficient mice. J Virol 77:7034-7040.

Rangachari V, Reed DK, Moore BD, Rosenberry TL (2006) Secondary structure and interfacial aggregation of amyloid-beta(1-40) on sodium dodecyl sulfate micelles. Biochemistry 45:8639-8648.

Sanchez-Pulido L, Devos D, Valencia A (2002) BRICHOS: a conserved do- main in proteins associated with dementia, respiratory distress and cancer. Trends Biochem Sci 27:329-332.

Sato T, Kienlen-Campard P, Ahmed M, Liu W, Li H, Elliott JI, Aimoto S, Constantinescu SN, Octave JN, Smith SO (2006) Inhibitors of amyloid toxicity based on beta-sheet packing of Abeta40 and Abeta42. Biochemistry 45:5503-5516.

Tomidokoro Y, Lashley T, Rostagno A, Neubert TA, Bojsen-Moller M, Braendgaard H, Plant G, Holton J, Frangione B, Revesz T, Ghiso J (2005) Familial Danish dementia: co-existence of Danish and Alzheimer amyloid subunits (ADan AND A $\{$ beta $\}$ ) in the absence of compact plaques. J Biol Chem 280:36883-36894.

Vidal R, Frangione B, Rostagno A, Mead S, Revesz T, Plant G, Ghiso J (1999) A stop-codon mutation in the BRI gene associated with familial $\mathrm{Br}$ dementia. Nature 399:776-781.

Vidal R, Revesz T, Rostagno A, Kim E, Holton JL, Bek T, Bojsen-Moller M, Braendgaard H, Plant G, Ghiso J, Frangione B (2000) A decamer duplication in the 3' region of the BRI gene originates an amyloid peptide that is associated with dementia in a Danish kindred. Proc Natl Acad Sci USA 97:4920-4925.

Vidal R, Calero M, Revesz T, Plant G, Ghiso J, Frangione B (2001) Sequence, genomic structure and tissue expression of Human BRI3, a member of the BRI gene family. Gene 266:95-102.

Wickham L, Benjannet S, Marcinkiewicz E, Chretien M, Seidah NG (2005) Beta-amyloid protein converting enzyme 1 and brain-specific type II membrane protein BRI3: binding partners processed by furin. J Neurochem 92:93-102. 